\title{
Necrophiliac Behavior in the Common Asian Toad, Duttaphrynus melanostictus (Schneider 1799) in Western India
}

Harshil Patel ${ }^{1}$, Pranav Vaghashiya ${ }^{2}$, and Shantilal K. Tank ${ }^{1}$

${ }^{1}$ Department of Biosciences, Veer Narmad South Gujarat University, Surat-395007, Gujarat, India (harshilpatel121@gmail.com)

${ }^{2}$ Amrutam, 193/Bapunagar, Joshipura, Junagadh-362002, Gujarat, India

$\mathrm{N}$ ecrophilia, also known as thanatophilia or Davian behavior, is a form of reproductive behavior that involves attempted copulation with dead conspecifics; it has been reported in several species of all major groups of tetrapods (Dickerman 1960; Lehner 1988; Sinovas 2009; Costa et al. 2010). Among anurans, Davian behavior has been reported in a few species from North and South America and Europe (Bedoya et al. 2014; Bettaso et al. 2008; Brito et al. 2012; Izzo et al. 2012; Meshaka 1996; Mollov et al. 2010; Sinovas 2009). Although a widespread phenomenon, no published reports document this behavior in any Asian anurans. Here, we provide the first report of necrophilia in an Asian species, the Common Asian Toad (Duttaphrynus melanostictus
[Schneider 1799]), which is widely distributed in the IndoMalayan region.

On 13 June 2013 at approximately $2230 \mathrm{~h}$ on a road passing through a forest patch in the outskirts of Junagadh, Gujarat, India $\left(23^{\circ} 31^{\prime} 52^{\prime \prime} \mathrm{N}, 70^{\circ} 28^{\prime} 46^{\prime \prime} \mathrm{E} ; 95 \mathrm{~m}\right.$ asl), we found an adult male Duttaphrynus melanostictus in axillary amplexus with a road-killed conspecific female (Fig. 1). The rhythmic contractions of the male indicated that it was trying to copulate. The pair remained in the same position for 4-5 min until the male released the corpse and retreated into nearby vegetation when approached by one of us (PV).

We could not confirm whether the pair was in amplexus when the female was run over. However, we presume that

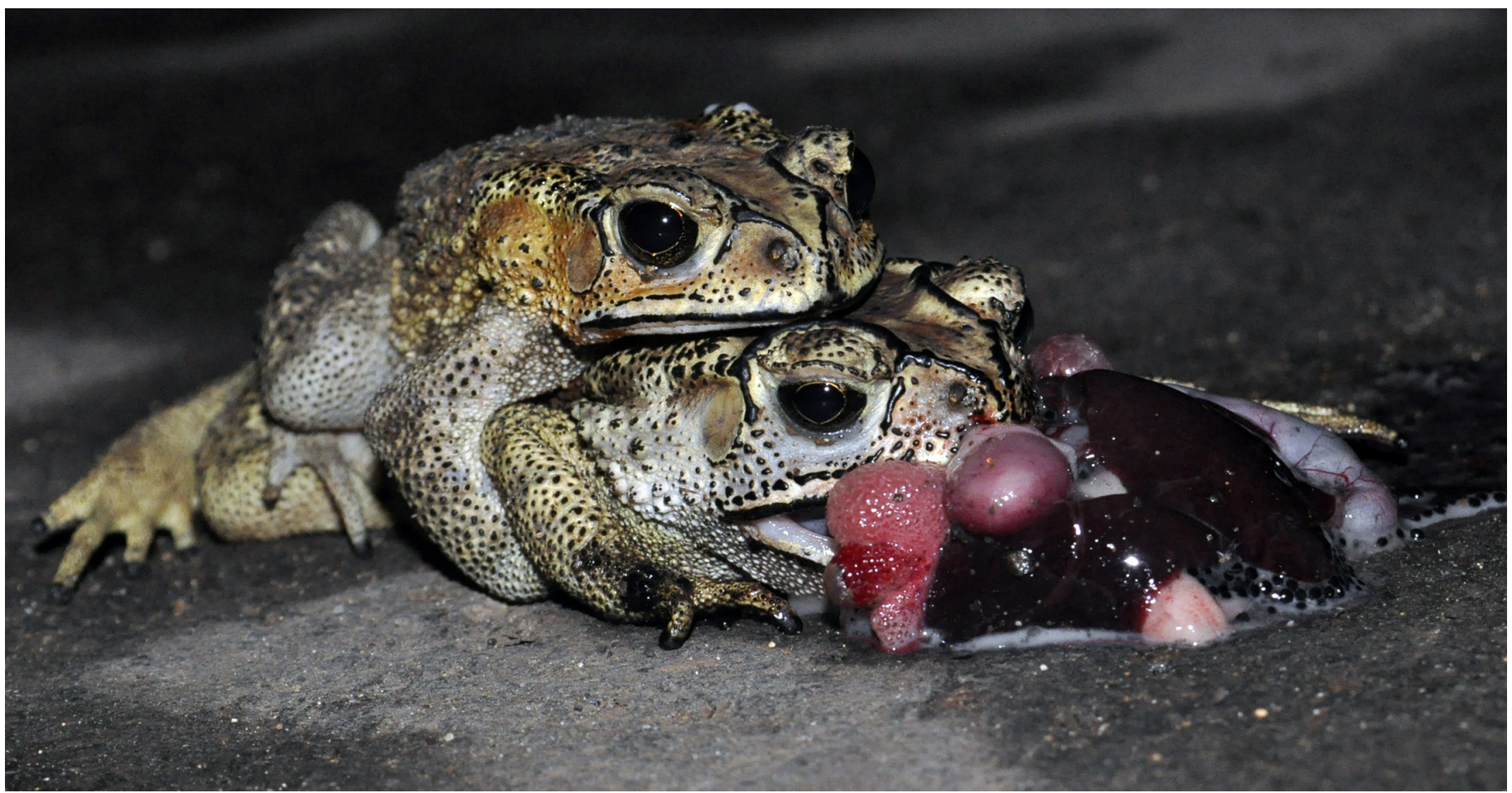

Fig. 1. An adult male Common Asian Toad (Duttaphrynus melanostictus) in amplexus with a road-killed conspecific female. 
the male was attracted by the chemical trail left by the female as the female was probably secreting pheromones to attract breeding males. The high number of female Duttaphrynus melanostictus killed on Indian roads passing through forested areas during the early monsoon season could elicit a high frequency of Davian behavior. A similar phenomenon has been reported in some explosive breeding anurans in the United States (Meshaka 1996). The cause of necrophilia is considered to be a lack of proper recognition by males while seeking a mate, which results in behavioral mistakes (Bedoya et al. 2014; Bettaso et al. 2008; Brito et al. 2012; Sinovas 2009). However, necrophilia may be functional in anurans (Izzo et al. 2012) if persistent males succeed in promoting the ejection of oocytes from the abdominal cavities of dead females and fertilize them. Future studies on breeding ecology and controlled experiments will enable us to better understand Davian behavior in amphibians.

\section{Acknowledgments}

We are thankful to Amit Vaghashiya and Elvis Katara for their help during fieldwork. This work was supported by the Department of Science \& Technology, New Delhi (Fellowship IF 130480 to HP).

\section{Literature Cited}

Bedoya, S.C., J.C. Mantilla-Castaño, and I.M. Pareja-Márquez. 2014. Necrophiliac and interspecific amplexus in Dendropsophus columbianus (Anura: Hylidae) in the Central Cordillera of Colombia. Herpetology Notes 7: 515-516.

Bettaso, J., A. Haggarty, and E. Russell. 2008. Rana boylii (Foothill Yellow-legged Frog). Necrogamy. Herpetological Review 39: 462.

Brito, L.B.M., I.R. Joventino, S.C. Ribeiro, and P. Gascon. 2012. Necrophiliac behavior in the "cururu" toad, Rhinella jimi Steuvax, 2002, (Anura, Bufonidae) from Northeastern Brazil. North-Western Journal of Zoology 8: 365-366.

Costa, H.C., E.T. Silva, P.S. Campos, M.P.C. Oliveira, A.V. Nunes, and P.S. Santos. 2010. The corpse bride: A case of Davian behavior in the Green Ameiva (Ameiva ameiva) in southeastern Brazil. Herpetology Notes 3: 79-83.

Dickerman, R.W. 1960. "Davian behaviour complex" in ground squirrels. Journal of Mammalogy 41: 403.

Izzo, T.J., D.J. Rodrigues, M. Menin, A.P. Lima, and W.E. Magnusson. 2012. Functional necrophilia: A profitable anuran reproductive strategy? Journal of Natural History 46: 2961-2967.

Lehner, P.N. 1988. Avian Davian behaviour. Wilson Bulletin 100: 293-294.

Meshaka, W.E. Jr. 1996. Anuran Davian behavior: A Darwinian dilemma. Florida Scientist 59: 74-75.

Mollov, I.A., G.S. Popgeorgiev, B.Y. Naumov, N.D. Tzankov, and A.Y. Stoyanov. 2010. Cases of abnormal amplexus in anurans (Amphibia: Anura) from Bulgaria and Greece. Biharean Biologist 4: 121-125.

Sinovas, P. 2009. Bombina variegata (Yellow Fire-bellied Toad). Mating Behavior. Herpetological Review 40: 199. 